\title{
A New 'Lexicon' of Land Degradation: Toward a Holistic Thinking for Complex Socioeconomic Issues
}

\author{
Gianluca Egidi ${ }^{1}$, Luca Salvati ${ }^{2, *}$, Pavel Cudlin ${ }^{3}$, Rosanna Salvia ${ }^{4}\left(\mathbb{D}\right.$ and Manuela Romagnoli ${ }^{5}$ (i) \\ 1 Department of Agricultural and Forestry scieNcEs (DAFNE), Tuscia University, Via S. Camillo de Lellis, \\ I-01100 Viterbo, Italy; egidi.gianluca@unitus.it \\ 2 Council for Agricultural Research and Economics (CREA), Viale S. Margherita 80, I-52100 Arezzo, Italy \\ 3 Global Change Research Institute (CzechGlobe), Lipova 9, CZ-37005 Ceske Budejovice, Czech Republic; \\ cudlin.p@czechglobe.cz \\ 4 Department of Mathematics, Computer Science and Economics, University of Basilicata, Via Nazario Sauro, \\ 85, 85100 Potenza, Italy; rosanna.salvia@unibas.it \\ 5 Department of Innovation in Biological, Agri-food and Forest Systems (DIBAF), Tuscia University, \\ Via S. Camillo de Lellis, I-01100 Viterbo, Italy; mroma@unitus.it \\ * Correspondence: luca.salvati@crea.gov.it; Tel.: +39-06-615710
}

Received: 21 April 2020; Accepted: 20 May 2020; Published: 23 May 2020

\begin{abstract}
Land degradation is perceived worldwide as a key process of resource depletion, representing a paradigmatic issue in national and supra-national political agendas for the 21st century in both advanced and emerging economies. Trying to delineate a 'new lexicon of land degradation', the present study contributes to a holistic thinking of driving forces in local communities and regional contexts through a refined analysis and discussion of (apparent and latent) factors of land degradation. Rethinking the importance of five notions (time, space, scale, systems, and response) having an intimate linkage with land degradation allows a refined understanding of socio-environmental dynamics and the most appropriate actions to combat (or mitigate) land resource depletion. The conclusions summarize the rationale proposed in this work, and provide a brief outlook on future research addressing land degradation, its drivers and consequences.
\end{abstract}

Keywords: process; space; time; system; governance

\section{Introduction}

Becoming progressively more volatile and less predictable over time and space, ecosystem dynamics in both advanced economies and emerging countries reflect a clear on-site operational dimension [1-5]. Although with sometime important off-site effects, the 'risk' dimensions (biological, technological, economic) associated with ecosystem dynamics are intrinsically and intimately related with theoretical notions and complex empirical issues such as scale, processes, gradients, sustainability, resilience, and governance. These issues are often considered hegemonic concepts in social science [6-9] and form the necessary base for a comprehensive investigation of multifaceted biophysical and socioeconomic contexts [10-12]. By reflecting complex ecosystem dynamics characterized by multiple dimensions of ecological risk, land degradation is a basic process of natural resource deterioration becoming a particularly important issue in country and supra-national political agendas for the 21st century [13-15]. Defined as a long-term decline in soil productivity, land quality and ecosystem functioning, land degradation processes seem to expand rapidly at the global scale, especially in the dry lands of some African and Asian countries, in Latin America, and in Mediterranean-type ecosystems; in many cases, ecosystems in non-arid (or even non-dry) areas are demonstrated to be affected as well [16]. According to FAO data [17], nearly 30 per cent of forest land, 20 per cent of cropland and 10 per cent of pastures have undergone land/soil degradation in recent times. 
Land Degradation-intended as a reversible process-is conceptually split from the notion of desertification risk [18], defined as a peculiar form of land deterioration that implies the irreversible loss of capability for a sustainable crop production. United Nation Convention to combat Desertification [18] defined desertification as a 'land degradation in arid, semi-arid and dry sub-humid areas resulting from various factors, including climatic variations and human activities'. In these regards, land degradation is perceived as a major threat causing a long-term decline in soil productivity, weakening socioeconomic sustainability and exposing land to a higher risk of desertification [19-22]. In advanced economies, land degradation has become a particularly serious issue, and continuous trends toward soil depletion and desertification in well-known hotspots are exemplificative in this direction for the intrinsic linkage between climate change and rising anthropogenic pressures [23-26]. In these countries, land degradation is a particularly vivid example of the mutual interaction among ecological and socioeconomic systems [27-30], intrinsically shaped by the interplay of proximate causes and underlying factors [31-33].

At the same time, land degradation implies more general processes of ecosystem depletion- not restricted to soil ecological damage-involving the (more or less rapid) deterioration of other two environmental components (namely vegetation and water), whose assessment should be regarded as a part of more ambitious early-warning system of land degradation monitoring. According to FAO [34], the concept of land is more extensively formulated as "a delineable area of the Earth's terrestrial surface, encompassing all attributes of the biosphere immediately above or below this surface, including those of the near-surface climate, the soil and terrain forms, the surface hydrology (including shallow lakes, rivers, marshes and swamps), the near-surface sedimentary layers and associated groundwater reserve, the plant and animal populations, the human settlement pattern and physical results of past and present human activities". Consequently, Henry et al. [35] provide a more holistic definition of land as a "terrestrial system that comprises the natural resources (soil, near surface air, vegetation and other biota, and water), the ecological processes, topography, and human settlements and infrastructure that operate within that system". Holistic approaches to land degradation are clearly grounded on extensive definitions of land, going beyond the strict boundary of the 'soil depletion' issue [36-38].

Recent works (re)discuss the importance of some key words when providing an interpretative framework to multiple processes of land degradation worldwide [39]. A new lexicon-with both theoretical value and practical application-will contribute to (re)frame a global issue such as land degradation, one of the most relevant ecosystem disturbance in recent times, revealing the pressing need to integrate the characteristic dimensions of change into a unique analysis' framework [40]. Under conditions of increasing uncertainty and risk for ecosystems' functioning worldwide [41], the present contribution emphasizes the appropriateness of a refined understanding of multidimensional ecological dimensions through formulation of an interpretative framework grounded on five basic notions (time, space, scale, system, response), that can be integrated for a better representation of ecosystem functioning [42].

This approach contributes to a re-thinking of key dimensions of change in socioeconomic contexts experiencing land degradation [43-45]. More specifically, this study emphasizes the following issues in the next sections: (i) considering together ecological and socioeconomic dimensions leading to different forms of land degradation over both time and space, (ii) providing a refined understanding of the consequences of socioeconomic change in open systems, depending on the observation scale and, finally, (iii) proposing a more comprehensive investigation of the potential response that societies may implement in order to mitigate land degradation [46]. Building on a new lexicon of land degradation based on a philosophical and operational revision of few basic concepts [47], our paper concludes with a summary outlook on future research dealing with land degradation in contemporary socioeconomic systems.

\section{Time: Ecological Processes and Environmental Spirals}

While impacting soil fertility, land degradation involves ecological and economic processes that characterize the ecosystem at different temporal scales [48]. This assumption implies that (global 
and regional) socioeconomic processes can be seen as relevant drivers of land degradation [49-51]. Ecological complexity and the socioeconomic fragmentation of local systems experiencing land degradation are serious limitations to the development of refined empirical approaches and efficient mitigation strategies over appropriate time windows [52-55]. For instance, considering enough long time intervals, land-use transformations depend not only on urbanization, industrialization, tourism development, and crop intensification, but are also increasingly influenced by depopulation, economic marginalization, and land abandonment in rural districts [56-59]. Shedding light on the abovementioned processes is necessary to clarify the distinctive interactions among environmental and socioeconomic dimensions at the relevant temporal scale [60]. A complete understanding of the causes and consequences of land degradation in local systems should consider multiple time windows when approaching together socioeconomic, cultural, institutional, and ecological issues [61-64]. The use of a specific time scale may be coherent with a general strategy of sustainable development containing land degradation, while likely being inappropriate when investigating the resilience potential of a given local system, changing rapidly with the impact of multiple feedbacks at different temporal scales $[61,62]$. Although mainstream literature has investigated the relationship between land degradation and selected socioeconomic drivers at various temporal scales, a refined, comprehensive framework requires additional findings and comparative evidence from specific world regions [63,64].

For instance, impact of time scales on soil degradation has been widely recognized, since this process results from climate, hydrological, and ecological interactions, with implications for local socioeconomic systems [65-67]. On the contrary, the impact of land-clearance timing on soil degradation should be better clarified, since vegetation removal may lead to an increased overland flow affecting runoff rates more than any other ecological factor [68]. The complex interplay of environmental conditions and socioeconomic dynamics makes the identification of approaches investigating the role of time scales in land degradation processes particularly difficult [69-72]. Such approaches which require sophisticated quantitative techniques (including - but not limited to-statistical time series analysis decomposing temporal autocorrelation from serial and spatial autocorrelation) and more flexible policy strategies, with general guidelines emanated at the national or regional level, and adapting to local contexts under rapid evolution [73-76]. While contributing differently to land degradation, ecological and economic factors create enough complex spatio- temporal patterns of resource degradation along geographical gradients [77]. The ecological consequences of such dynamics are usually measurable in terms of increasing spatial divides in the level of land sensitivity to degradation because of, e.g., unbalanced resource availability [78]. The same rationale cannot be applied directly to time dimensions [79]. Consequently, a key issue such as socioeconomic disparities requires an integrated, multi-scale policy approach giving the appropriate role to processes oriented along time, and not only over space [80].

Building-up adequate methodologies to assess the dependence of environmental and economic drivers of land degradation over multiple time scales is a particularly hard task because of heterogeneity of cause-effects relationships and the multiple, mostly unpredictable linkages between environmental sensitivity and anthropogenic activities [81-84]. Various data sources have been used with the aim at developing multi-temporal information systems based on multi-domain indicators of climate, soil, vegetation, and land management quality, among others, and identifying the appropriate temporal scale of human-induced trends of land degradation [85-87]. The recognition, quantification and temporal representation of complex processes of land degradation definitely benefit approaches identifying breakpoints and structural changes in the evolution of local socioeconomic systems [88]. Assuming that a temporary (or permanent) decline in the soil productive capacity is an early warning of land degradation, a refined assessment of the importance of time scales in ecosystem functioning is relevant for both field assessors and planning actors [89]. This will contribute to avoiding linear interpretations of land degradation as a simple process with clear outcomes [90]. For instance, although particularly effective in stimulating stakeholders' awareness of land degradation processes (Figure 1), the evaluation of land vulnerability to desertification based on individual target indicators, e.g., an index 
assessing climate aridity, can be oversimplified, often demising the intimate linkages between climate, soil, vegetation and human pressure at the base of any desertification process.
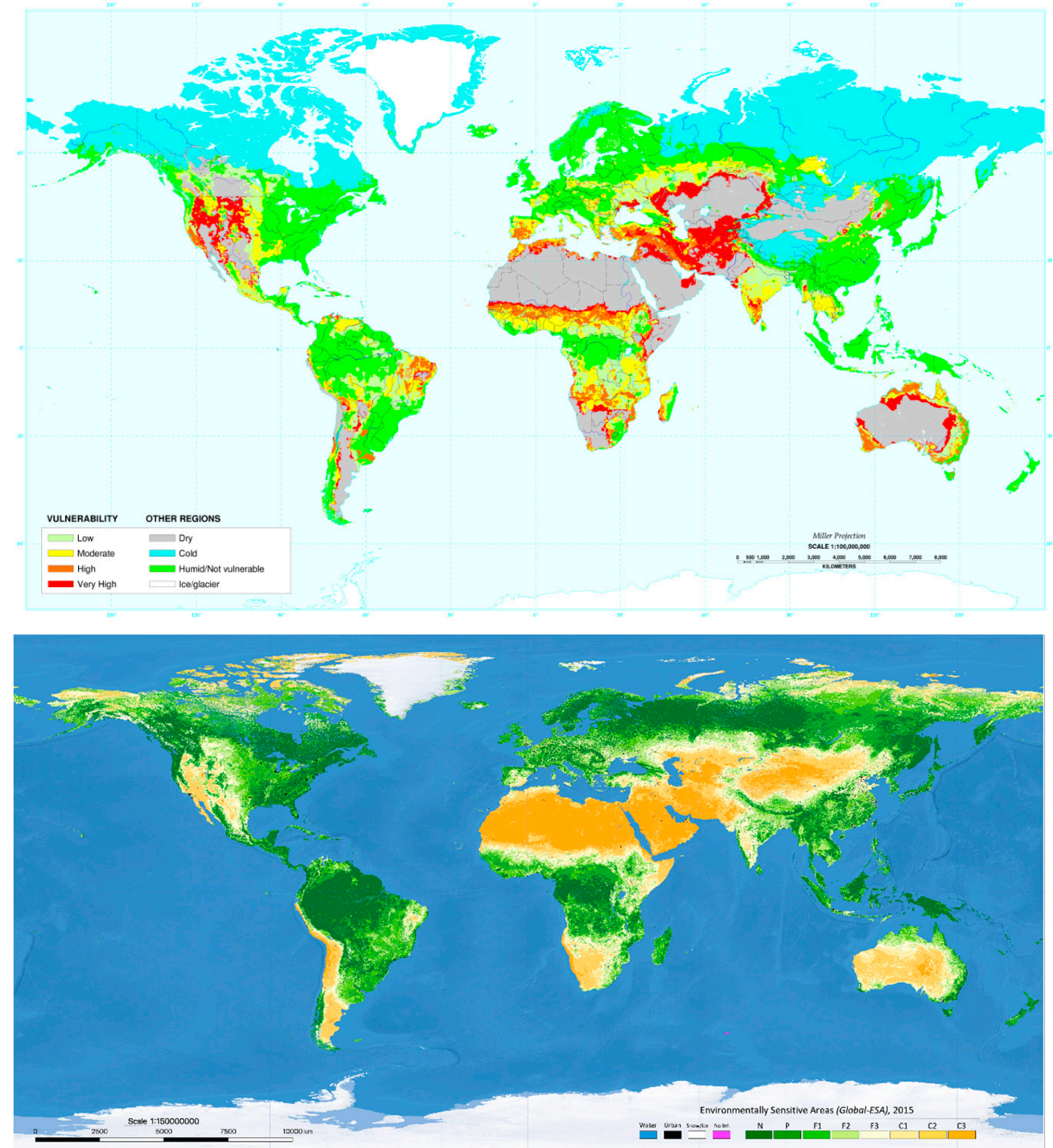

Figure 1. (Upper panel) A global map of land vulnerability to desertification based on climate aridity index (Source: US Department of Agriculture, Natural Resources Conservation Service, Soil Survey division, World Soil Resources, http://commons.wikimedia.org/wiki/Image: Desertification_map.png). (lower panel) A global map of land vulnerability to desertification based on the application of the Environmentally Sensitive Area (ESA) approach considering climate, soil, vegetation and human pressure (8 classes with increasing land vulnerability were shown: N: not affected; P: potentially affected; F1-3: 'Fragile' areas; C1-3: 'Critical' areas; Source: [91]).

In this regard, Figure 1 compares a global cartography of vulnerability to desertification based on a single indicator (climatic aridity) with a vulnerability map constructed using a more complex index that integrates four dimensions of analysis (climate, soil, vegetation/land-use and human pressure). Although the global geography of vulnerable areas appears similar in the two maps, differences can be observed at the regional scale, highlighting how the evaluation of a complex phenomenon such as land 
degradation requires integrated approaches that compose information from different data sources and that cover various drivers of change. Interplays among such factors usually articulate over different time horizons, being longer for soils—changing less rapidly over time-and shorter for vegetation and human pressure. However, up to few years ago, simplified approaches-based, e.g., on the analysis of individual indicators - were at the base of many statutory approaches to delineate vulnerable areas in national action plans to combat desertification.

One example was provided by the national action plan to combat drought and desertification in Italy, prepared and approved in 1999, that identified sensitive areas to desertification in the country by using a simplified system of thresholds elaborating the aridity index in agreement with international standards (e.g., United Nations Environmental Program). Comparing environmental conditions in 1990 and 2000, Figure 2 illustrates the spatio-temporal evolution of sensitive lands based on this linear approach in Italy compared with a more complex evaluation of the same concept based on the Environmental Sensitive Area index that integrates three dimensions of climate quality, soil quality and vegetation/land-use quality. Assuming land sensitivity as an eminently dynamic issue, the ESA approach delineates a more articulated spatial pattern of land sensitivity in Italy, going beyond the simplified and partial information derived from analysis of the climate aridity index. When considering changes over time in the studies time interval (1990-2000), the illustrated pattern underlies particularly complex territorial dynamics that should be considered in specific policy approaches.
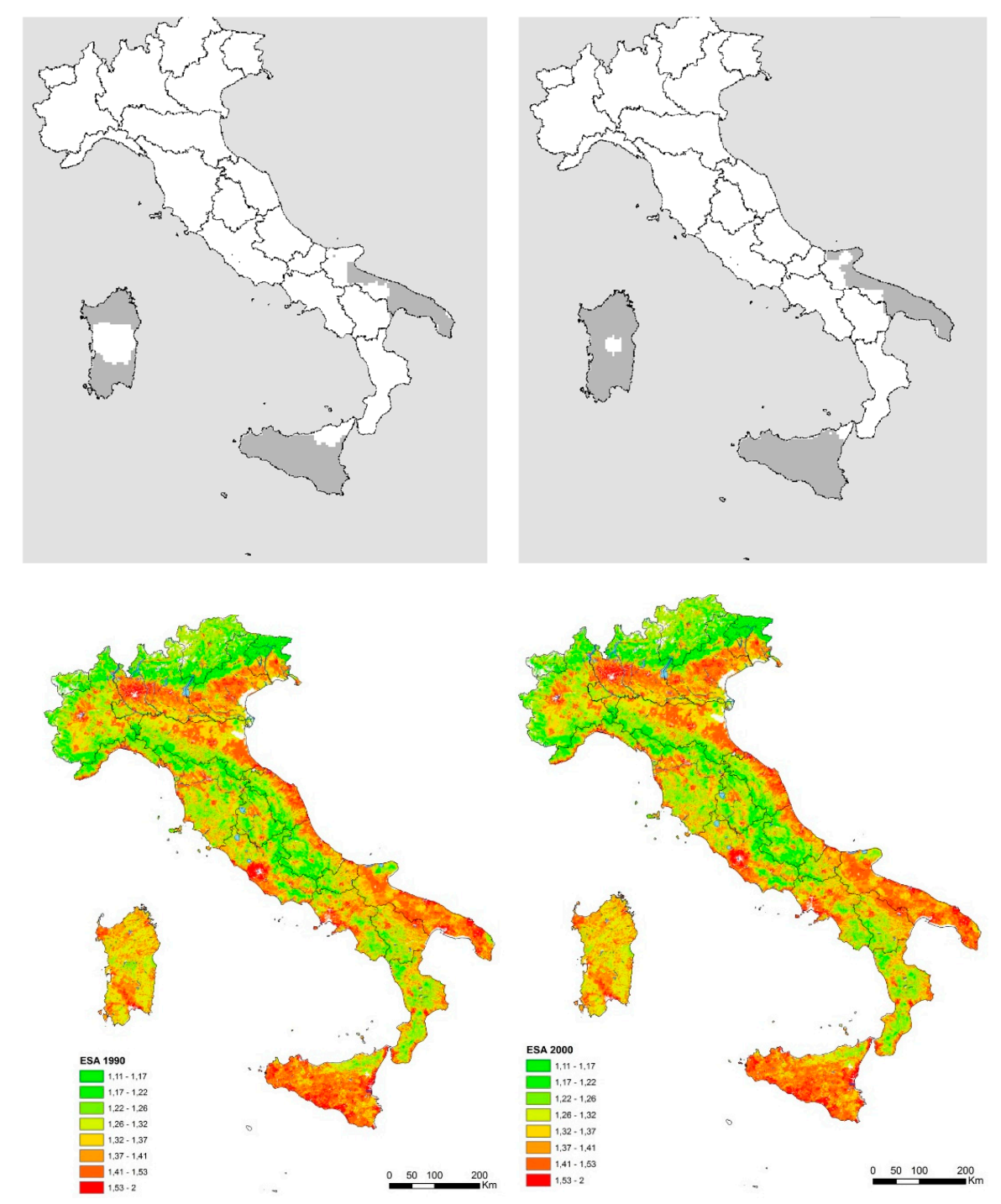

Figure 2. A simplified, statutory delineation of sensitive areas to desertification in Italy [12] based on 
the UNEP climate aridity index (upper panel, left: 1990; right: 2000) and the spatial distribution of a more complex index of land sensitivity to desertification (ESA) based on climate, soil and vegetation quality [4] (green and red, respectively, indicate low and high sensitivity to desertification).

\section{Space: The Regional Differentiation in Landscapes and Degradation Forms}

Monitoring land quality and ecological risks benefits from the formal division and spatial representation of target variables and processes into homogeneous regions [92]. The definition of 'region' — an eminently 'geographic' notion—depends on the research argument, scholar's sensibility, and availability of relevant information [93]. Technical improvements in Geographic Information Systems (GIS) and Decision Support Systems (DSS) [94-96], statistical-cybernetic techniques [97-99], and data mining procedures that promote the adoption of multivariate analysis for variables' regionalization [100-102] have raised (and fueled) demand for geo-referenced data, spatial tagging and consistency in areal definition [103-105]. Procedures investigating regional contexts and forming a knowledge base from which to implement effective policy strategies have been increasingly proposed in different fields of study and intervention [106-109]. An approach grounded on the exploration of multiple drivers involved in land degradation processes seems to be particularly appropriate to achieve a precise evaluation of environmental quality and soil degradation, providing a more articulated assessment of the intimate, multivariate relationships with socioeconomic local systems [110]. A refined analysis of the mutual feedbacks between environmental and socioeconomic drivers is necessary when referring to complex processes that are intrinsically heterogeneous at the landscape scale and change rapidly over geographical gradients [111]. In this regard, addressing issues of spatial comparability when combining ecological variables and socioeconomic indicators is increasingly required [112], since they are usually calculated, expressed and mapped at vastly different spatial scales and using distinctive geographical domains of aggregation (e.g., eco-regions or other spatial partitions with a clear ecosystem meaning and rationale for ecological variables; administrative units for socioeconomic factors). Computational problems such as the Modifiable Area Unit Problem, a typical issue in the ecological analysis of socioeconomic dimensions based on indicators aggregated on defined (administrative) spatial scales, should be considered in such contexts. Geo-spatial techniques regionalizing variables over homogeneous lattices seem to be appropriate to contain the analysis' biases resulting from such problems [110].

Discussing regional aspects of land degradation contributes to policy design for sustainable development [113]. Because of the multifaceted factors involved in land degradation, methodological issues (e.g., reflecting a trade-off in every sampling technique between spatial precision, operational feasibility, measurability and coherency with the original concept) may arise if key messages from changing landscapes are systematically demised [114]. In these regards, appropriate geographical indicators assure the most effective use of the accessed data. Indicator versatility results in (a supposedly easy) integration with data produced under various methodologies and formats, including remote sensing, field measurements, and statistical surveys [115]. A basic problem regarding the notion of 'space' and the operational definition of 'regions' is intrinsically grounded in the choice of relevant indicators of land degradation [116].

Indicators are intrinsically classified into different groups based on their epistemological linkage with the main concept of land degradation [117]. Among them, we can distinguish hard indicators, with a widely documented linkage with the dominant concept, having received validation from field studies, from soft indicators-having an indirect connection with land degradation [118]. Hard indicators include variables assessing, e.g., soil degradation issues with a direct linkage with land degradation, such as soil erosion, salinization, compaction, sealing and the related processes. Soft indicators include variables that are supposed to be indirectly connected with land degradation, such as demographic dynamics, population aging, or average farm size. These are generally defined as 'contextual indicators' and are included as ancillary/supplementary variables to general models estimating/interpreting complexity of land degradation processes [119]. However, soft indicators revealed to be particularly 
useful in defining the background socioeconomic context of vulnerable land (or regions) supporting the results of quantitative and refined analyses based on field sampling or remote sensing [120]. With both hard and soft indicators, working at various spatial scales, from local to regional, revealed suitable to delineating criteria to include (or exclude) variables assessing land vulnerability, especially when long time series of suitable indicators are available [121]. In this ambit, providing spatially homogeneous information regarding the intrinsic rate of land degradation at a given territorial scale and the geographic variability of the related ecological and anthropogenic drivers represent a basic need for multi-scale policy design and mitigation strategies [122].

\section{Scale: The Intrinsic Representation of Regional Processes of Change}

Based on the framework illustrated in the two earlier chapters, scale can be declined in different (positive and normative) issues, having time and space as the main operational dimensions. The intimate set of definitions proposed so far is tailored for analysis at sufficiently larger scales, being rather vague for studies at both regional and local scales [123]. Scaling down requires refined conceptual frameworks aimed at better defining land vulnerability [124]. Different operational approaches to land degradation have been therefore proposed according to landscape characteristics, territorial context, and geographical scale [91,125-127]. For instance, degraded land is considered as a soil typical of dry climates that performs a sort of 'functional sterility', meaning that agriculture and forestry are currently no longer either economically or ecologically sustainable at those places [128]. This notion is intimately associated with land sensitivity to degradation. On the contrary, some environmental characters similar with those observed for desertified land may characterize vulnerable land. However, land degradation processes in these areas are still reversible because of the existence of some factors that may (directly or indirectly) mitigate land degradation (e.g., vegetation cover against soil erosion, sustainable agricultural practices, traditional rural culture promoting re-use or re-cycle of materials and resources).

Standardized and homogeneous databases integrating basic indicators at varying spatio-temporal scales, with the aim of identifying sensitive areas and quantifying land at risk of degradation, are still scarce and with a mostly local coverage. Socioeconomic indicators and future scenarios of local system evolution are especially lacking in these kinds of databases. Geo-spatial databases compiled with homogeneous and reproducible criteria and with larger spatial coverage assure a continuous, joint monitoring of biophysical and socioeconomic contexts leading to land degradation. Availability of reliable data sources and geo-spatial databases appropriately compiled for decision support is considered a major concern (i) stimulating future research that investigates specific environmental processes characterizing degraded land at both regional and local scales, and (ii) identifying a variety of measures aimed at defining a complete policy framework combating land degradation $[129,130]$. According with the National Research Council [131], "geographical research elucidating patterns of inequality and the processes producing those patterns at different spatial scales can shed light on the inequality impacts of the changing socioeconomic environment, as well as the links between poverty and consumption patterns. The geopolitical framework that dominated the post-World War II era has also come apart in the face of economic and social upheaval, raising the need for expanded research on the territorial agendas of influential governments and groups, the changing significance of boundaries, and the role of resource scarcity in cooperation and conflict". With a thorough discussion of the overlaps between spatial scales and temporal analysis, this contribution envisages the role of systems' dynamics characterized by "multiple interlocking scales". In these regards, studies on the relationship between land degradation processes and spatial scales require a more specific outline of appropriate multi-scale policy frameworks responding to such processes of degradation [60], focusing on practical examples that reflect the relevance of multi-scale interpretative formats for spatial planning and policy.

Assuming that similar rules in the environment-economy relationship can be valid irrespective of spatio-temporal scale, use of a standardized framework exploring (and similar models explaining) spatial concentration, sectoral specialization and the (negative) externalities of economic production at vastly different scales appears to be desirable [132]. In these regards, the notion of scale operationally 
provides meaningful insights to understanding (i) the impact of socioeconomic and environmental gradients accounting for the spatial distribution of land resources and their potential degradation, (ii) the role of globalization, spatial polarization, and economic localization on environment dynamics, e.g., exploring the effect of production scales from a spatial perspective and the implications of economic decentralization for (multi-domain) environmental policy [133-135].

Scale is therefore the appropriate conceptual mediator when evaluating the interaction between biophysical dynamics and socioeconomic factors to define areas potentially exposed to desertification. Multi-scale indexes of land vulnerability to degradation have been proposed, although a still limited number of studies have attempted to quantify changes over time in land degradation processes [136]. In such a context, moving from a single-site to cross-sites approaches contains the issues associated with data comparability across regions and countries [137]. At the same time, focusing on scale issues allows us to investigate processes whose knowledge and interpretation is intrinsically influenced by the level of observation, since they depend on driving forces acting at different spatial scale [138]. Being sometime regarded as a scale-dependent phenomenon, convergence in the level of land vulnerability to degradation across space reflects the impact of long-term paths of sustainable development coordinated over different temporal scales [87]. For such reasons, a multi-scale policy strategy, based on integrated, while distinctive, actions at both national, regional and local levels, is supposed to be more effective in contrasting land degradation [139].

\section{Systems: A Closer Look to Sustainability Paths}

Land degradation has been basically approached at 'on-site' levels, focusing specifically on biophysical drivers of change. Relatively few studies deal with the same problem on a regional scale, focusing more specifically on the anthropogenic factors regulating ecological processes of land degradation [140,141]. With this line of thinking, the relationship between 'sustainable development' and economic growth outlines the intrinsic limits in a complete understanding of the multiple interactions between biophysical and socioeconomic dynamics [142]. While interest for integrated analyses of local systems experiencing land degradation has been higher in more recent times, it was assumed that the sustainable management of land resources depends on a series of political, economic, demographic and ecological factors, often decoupled or weakly coordinated over time and space [143]. While sustainable development is clearly among the most powerful responses to environmental degradation and natural resource depletion, economic performances, social inequality, institutional policies and their relations with ecological quality/environmental degradation at large provide examples of the interaction between immediate causes and background context in local systems undergoing land degradation [144]. While still ambiguous, the definition of 'sustainable development' - as a process that improves the quality of human life without affecting ecosystems' quality-gives the idea that sustainability has quantifiable operational limitations as a policy process.

Taking the dualism between positive approaches (i.e., sustainability science) and the regulatory framework (i.e., sustainable development policies) establishing common objectives and values, the notion has been progressive evolved from simplified (but still coherent) definitions à la Bruntland, toward the emergence of increasingly holistic and integrated perspectives, which have received its maximum inspiration and practical application in the Agenda 2030. The post-2015 development agenda has been a complex process led by the United Nations since 2012 with the aim at defining the future global development framework that would update the Millennium Development Goals (MDGs). After extensive negotiation, the Agenda redesigned the objectives and targets of sustainable development, articulating them into objectives and targets, and including all 193 United Nations Member States and civil society in the action plan. The resolution of the objectives consists of a broad intergovernmental agreement that constitutes the Post 2015 Development Agenda, focusing on a key message entitled "Transforming our world: the 2030 sustainable development agenda". The Agenda is made up of 92 paragraphs outlining the 17 sustainable development goals, and the 169 goals and 232 associated indicators (Figure 3). 


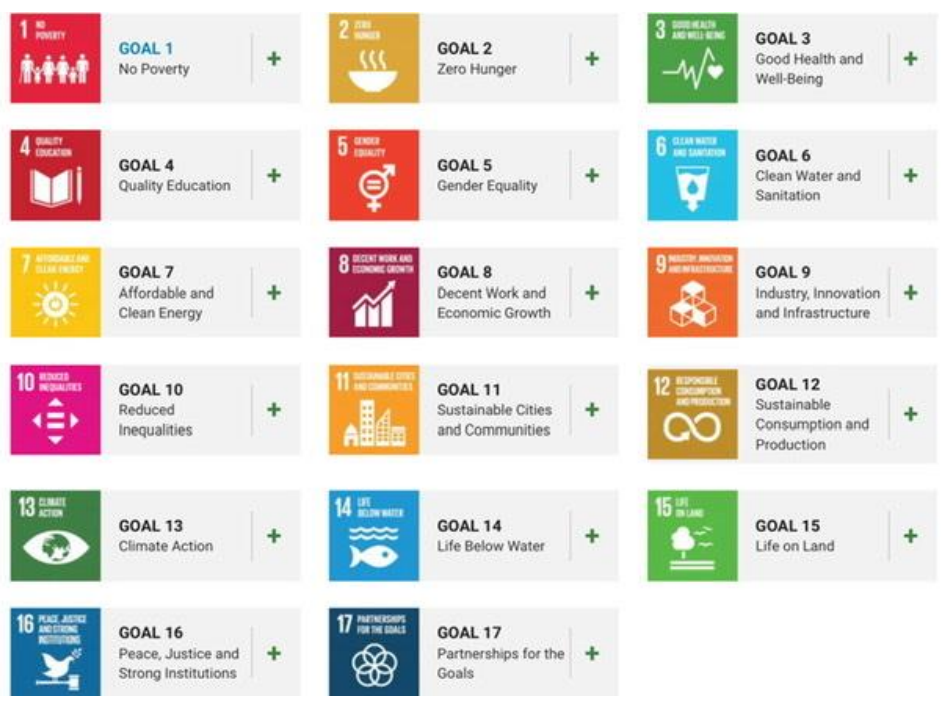

Figure 3. A summary of sustainable development goals in Agenda 2030 (source: Italian National System for Environmental Protection, SNPA).

Unlike the MDGs, the prefixed objectives of Agenda 2030 did not distinguish between developed and developing countries, since they affect all states without distinction, and this strategy appears to be an implicit contribution to the spatially balanced development theme of the sustainability paradigm. The holistic vision of Agenda 2030, encompassing intrinsically different ecological and socioeconomic dimensions, provides the appropriate rationale to address sustainable development under complex system conditions. Land degradation issues are intimately related with most of the Agenda 2030 dimensions. In these regards, the sustainable development goals indirectly paved the way for a more holistic and integrated evaluation of land degradation, outlining the need to reconnect local contexts with the ensemble of processes leading to landscape change and socioeconomic transformations.

In these regards, the distinction of processes acting as direct causes from those acting as contextual factors allows disentangling both the short- and long-term effects of land degradation on local systems [145]. Choice of the (empirical) model and selection of target variables involved in such processes add some key suggestions to the debate on the environmental-development nexus at the local system scale $[146,147]$. Multivariate exploratory statistical models and spatial/a-spatial regressions integrating socioeconomic variables with land-use and sustainable policy indicators demonstrate that (i) the environment- development nexus is particularly composite and variable in local systems, requiring more specific approaches avoiding simplification and linearization of complex issues, and that (ii) sustainable development components (economic, social, and environmental) affect policy and planning effectiveness in a mostly non-coordinated fashion [148,149].

Empirical frameworks based on traditional econometrics testing economic convergence/divergence were in turn proposed with the aim at interpreting local system dynamics, extending the approach to purely non-economic dimensions such as social and environmental issues [150,151]. A complete investigation of convergence (or divergence) to a common trajectory characterizing local system dynamics has consequences for a better understanding of the relationship between sustainable development, environmental quality, and social disparities, informing a more specific design of strategies contrasting land degradation [152,153]. Local system convergence toward a common socio-environmental evolution path also has implications for desertification mitigation and/or adaptation to global changes [43]. As a matter of fact, sustainable development in local systems is intended as spatially balanced and consistent over time. A holistic understanding of this growth path gives the opportunity to reconnect the debate on time, space and scale proposed (see the earlier chapters) into an interpretative framework grounded on complex system dynamics [53]. 


\section{Response: Coordinating Formal and Informal Actions}

Different types of land use may create (or consolidate) apparent (or latent) disparities in system functioning. In this regard, unsustainable forms of land use are supposed to be an important cause of land degradation [11]. In what measure human causes affect land degradation and which processes linking social inequality and economic polarization to ecological risk impact desertification have been clarified only partly [120]. More recently, a renewed interest in regional issues outlines how challenges such as spatial disparities and the linkage with land degradation require more integrated monitoring approaches and a complete re-design of policy response [41]. Socio-demographic and economic measures may significantly impact land degradation thanks to the intrinsic regulation of anthropogenic pressures; implications of such actions are measurable in terms of adaptation and mitigation to global change [1]. The formulation and implementation of social policies aimed at regulating migration, containing poverty and reducing inequalities especially in marginal areas, are crucial for sustainable development [78]. Under transparent and shared strategies supporting local communities, people-intended as the main actor of land degradation-more clearly understand, accept, and participate in the implementation of environmentally friendly practices [81].

Examples of social policies with indirect feedback on land degradation may help in this research frame [154-156]. First, as social inequality and poverty are frequently gendered phenomena, measures promoting an equitable participation of women and young to economic life (job market, entrepreneurship, land tenure) is increasingly required as a part of the wider set of actions possibly containing social exclusion [140]. Second, social policies with emphasis on human resource development (improving skills and knowledge of new technology, but also rediscovering traditional practices) are increasingly required since education and training schemes designed to address a sustainable management of land are considered effective actions in the mitigation of land degradation [132]. Third, permanent mechanisms of dissemination of the relevant practices and actions combating land degradation should address the informative asymmetry in more remote local communities [143]. Fourth, migration policies reducing land abandonment and depopulation of economically disadvantaged places should be an integral part of a broader social strategy articulated over multiple temporal and spatial frames, aimed at combating human desertification in marginal districts [157].

In this context, stakeholders' participation in policy strategies combating land degradation is a particularly ambitious target [133]. Assuming a great impact of changes in local systems on individual decisions, which in turn affect land degradation directly or indirectly, stakeholders have different perceptions of desertification risk and research is asked to identify practical mechanisms involving stakeholders in problem analysis and solution-finding [57]. Establishing and/or intensifying the dialogue between stakeholders, policy-makers, and citizens seem to be the right way ahead [44]. Within enhanced institutional platforms, stakeholder convergence on a consensus definition of 'land degradation' is still important in this line of thinking. Participatory processes, research and practical tools for policymakers remain the appropriate instruments enhancing future actions to combat desertification [39].

Policy impact analysis is essential to assess the repercussion for grassroots stakeholders experiencing the negative consequences of land degradation. Although policy formulation does not always result in a specific ground impact-since policies may have different explicit and implicit functioning mechanisms-the dynamic, non-linear nature of land degradation processes should definitely be considered when designing (or implementing) integrated measures of adaptation/mitigation [6]. At the same time, non-decision-making, non-formulation and non-implementation of dedicated strategies can be regarded as a tangible policy implementation [147]. Unfortunately, inaction costs have still not been sufficiently acknowledged in earlier studies [106]. As a result, policy implementation reflects a relatively fuzzy decision-making spectrum rather than a clear-cut set of decision option with specific reference to a given time schedule and spatial assemblage [43]. Based on the new lexicon proposed in this study, land degradation policies should be more effectively 
summarized into multi-level strategies acting at different scales. The take-home message is that policy strategies should evolve from driver-specific to process-specific, incorporating an operational dimension articulated over both time and space.

\section{Concluding Remarks}

Land degradation is intimately associated with some socio-environmental processes mentioned in the present study that significantly influence the future sustainable development path of any local system and the consequent implementation of effective policies finely tuning economic growth and natural resource conservation. A truly sustainable development path reflects the interplay of multiple human-nature interactions, distinctively underlying the causes, consequences, and implications of land degradation. By focusing together on direct factors and the underlying context, land degradation is a crucial dimension of the 'sustainable development' issue, since land use is a 'socially constructed' notion and an action relevant to human wellbeing when assuming soil productivity, land capability, agronomic practices and natural resource exploitation as basic elements shaping human-nature interactions [7]. Socioeconomic organization, spatial integration, and temporal coordination of local systems' development paths can be effectively discussed, having in mind the strict connection with the theoretical framework of sustainable development [91]; poverty, social inequality, migration are specific faces of this problem that require political interventions. At the same time, a strategy combating land degradation should incorporate actions to mitigate the negative impact of all these issues on soil and land quality, promoting the three dimensions of sustainability and the Agenda 2030 Sustainable Development Goals together.

By discussing five basic notions in both ecology and social science, considered as basic dimensions of change, our commentary delineates a complete 'land degradation' thinking, from field assessment to policy response. Summarizing examples of interactions among ecological factors, economic performances, cultural/social dynamics and political action, we outlined how addressing land degradation in a truly inclusive time-space interpretative framework requires permanent monitoring and effective policies together. Despite massive research efforts in the direction of designing more effective strategies preventing (or containing) desertification risk, sustainable development paths still need to incorporate a truly holistic (ecological and socioeconomic) management of land, delineating effective strategies to combat regional disparities $[23,114,145]$. This is particularly important because land degradation causes uncertainty in local systems' development paths [4]. Strategies aimed at reducing regional disparities, especially in marginal areas, are crucial to achieve a sustainable development maintaining high environmental standards and mitigate potential land degradation. At the same time, measures combating land degradation should contribute more intensively to the objective of sustainable development, being effective at different spatial and temporal scales. The intimate relation between desertification risk, population growth, urban-rural dynamics and economic expansion is a basic rationale orienting the design of a comprehensive policy framework towards sustainable development.

Strategies oriented toward a global Zero Net Land Degradation philosophy seem to be particularly appropriate to answer this complex issue. Zero Net Land Degradation implies that the extent of global degraded lands will decrease or at least remain stable [13]. To enable this scenario, the rate of global land degradation should not exceed that of land restoration [158]. The United Nations Convention to Combat Desertification envisages achieving this target by 2030 [159]. Despite being seemingly ambitious, the target of Zero Net Land Degradation could be achieved if degraded lands are restored to a considerable extent and, at the same time, unsustainable management practices are replaced with ones that preserve land [160]. Specific protocols aimed at managing permanent assessment and designing supportive policies/regulations enable an effective implementation of these steps, achieving the target of land degradation neutrality [161]. For instance, the REDD+ program (Reducing Emissions from Deforestation and forest Degradation) can be regarded as intimately linked with any Zero Net Land Degradation strategy. Forests are clearly at the core of this program and the 
fundamental role they play in climate change mitigation, by removing $\mathrm{CO}_{2}$ from the atmosphere and storing it in biomass and soils. This also means that when forests are cleared or degraded, they can become a source of greenhouse gas emissions by releasing that stored carbon. Halting deforestation is a cost-effective action that has a clear impact in reducing global emissions. Based on these premises, the REDD+ program - envisaging a sustainable management of forests aimed at integral conservation and enhancement of forest carbon stocks-is an essential part of the global efforts to mitigate climate change, indirectly contributing to land degradation containment.

Land degradation neutrality is also regarded as a key dimension of the Agenda 2030 Sustainable Development Goals, outlining the operational linkage between practices of (un)sustainable development and land degradation. Being intimately linked with a Zero Net Land Degradation strategy, the Sustainable Development Goals significantly cross the perimeter of sustainable development, to include higher-level dimensions that refer to broader and general issues such as sustainable styles of life, work, production and consumption, envisaging mechanisms of preservation (or reproduction) of basic resources, from the individual scale to the collective level [162]. By incorporating an integrated vision of the different dimensions of development, the innovative nature of the Agenda-and the intimately connected 'zero net' strategies-lies in the provision that all countries are called to contribute to the effort to bring the earth system on a path of sustainable development [163]. Even if the problems may vary according to the level of development achieved, this effort does not see any distinction between affluent countries and emerging economies [164,165].

Structural socioeconomic changes in local systems may positively influence environmental quality, thus reducing land vulnerability to degradation [123]. It is not enough to state that policies supporting economic growth are sufficient to contain land degradation [124], since additional factors counteract the (supposedly) positive environmental effect of local development [8]. In these regards, integrating practical measures that act at different operational scales (e.g., environmental/soil practices at the field level, social measures at district scale and economic policies with regional, country or supra-national coverage) represents a coherent response impacting together a number of interacting factors that exacerbate land degradation [22]. The operative coordination of multi-scale (national, regional, local) and multi-target (economic, social, environmental) policies is expected to improve the effectiveness of mitigation strategies in the light of the sustainable development of local systems exposed to land degradation.

Author Contributions: Conceptualization, L.S. and P.C.; methodology, M.R.; validation, G.E.; investigation, M.R.; resources, M.R.; writing — original draft preparation, L.S. and M.R.; writing—review and editing, R.S. and P.C.; visualization, G.E.; supervision, G.E.; project administration, G.E.; funding acquisition, M.R. All authors have read and agreed to the published version of the manuscript.

Funding: This research received no external funding.

Conflicts of Interest: The authors declare no conflict of interest.

\section{References}

1. Alados, C.L.; Puigdefábregas, J.; Martínez-Fernández, J. Ecological and socio-economical thresholds of land and plant-community degradation in semi-arid Mediterranean areas of southeastern Spain. J. Arid Environ. 2011, 75, 1368-1376. [CrossRef]

2. D'Odorico, P.; Bhattachan, A.; Davis, K.F.; Ravi, S.; Runyan, C.W. Global desertification: Drivers and feedbacks. Adv. Water Resour. 2013, 51, 326-344. [CrossRef]

3. Biasi, R.; Colantoni, A.; Ferrara, C.; Ranalli, F.; Salvati, L. In-between sprawl and fires: Long-term forest expansion and settlement dynamics at the wildland-urban interface in Rome, Italy. Int. J. Sustain. Dev. World Ecol. 2015, 22, 467-475. [CrossRef]

4. Ferrara, A.; Kelly, C.; Wilson, G.A.; Nole, A.; Mancino, G.; Bajocco, S.; Salvati, L. Shaping the role of 'fast' and 'slow' drivers of change in forest-shrubland socio-ecological systems. J. Environ. Manag. 2016, 169, 155-166. [CrossRef] [PubMed] 
5. Laguna, M.F.; Monjeau, J.A.; Abramson, G. Waves of desertification in a competitive ecosystem. Ecol. Model. 2019, 396, 42-49.

6. Veron, S.R.; Paruelo, J.M.; Oesterheld, M. Assessing desertification. J. Arid Environ. 2006, 66, 751-763. [CrossRef]

7. Sutton, P.C.; Anderson, S.J.; Costanza, R.; Kubiszewski, I. The ecological economics of land degradation: Impacts on ecosystem service values. Ecol. Econ. 2016, 129, 182-192. [CrossRef]

8. Feng, Q.; Ma, H.; Jiang, X.; Wang, X.; Cao, S. What has caused desertification in China? Sci. Rep. 2015, 5, 15998. [CrossRef]

9. Grainger, A. The Threatening Desert: Controlling Desertification; Routledge: London, UK, 2013.

10. Jiang, L.; Jiapaer, G.; Bao, A.; Kurban, A.; Guo, H.; Zheng, G.; De Maeyer, P. Monitoring the long-term desertification process and assessing the relative roles of its drivers in Central Asia. Ecol. Indic. 2019, 104, 195-208. [CrossRef]

11. Kassa, H.; Dondeyne, S.; Poesen, J.; Frankl, A.; Nyssen, J. Transition from forest-based to cereal-based agricultural systems: A review of the drivers of land use change and degradation in Southwest Ethiopia. Land Degrad. Dev. 2017, 28, 431-449. [CrossRef]

12. Salvati, L.; Mancini, A.; Bajocco, S.; Gemmiti, R.; Carlucci, M. Socioeconomic development and vulnerability to land degradation in Italy. Reg. Environ. Chang. 2011, 11, 767-777. [CrossRef]

13. UNCCD. Zero Net Land Degradation A Sustainable Development Goal for Rio+20. UNCCD Secr. Policy Brief 2011. Available online: http://www.unccd.int (accessed on 19 March 2020).

14. Wilson, G.A.; Juntti, M. Unravelling Desertification: Policies and Actor Networks in Southern Europe; Wageningen Academic Publishers: Wageningen, The Netherlands, 2005.

15. Reynolds, J.F.; Grainger, A.; Stafford Smith, D.M.; Bastin, G.; Garcia-Barrios, L.; Fernández, R.J.; Verstraete, M.M. Scientific concepts for an integrated analysis of desertification. Land Degrad. Dev. 2011, 22, 166-183. [CrossRef]

16. Dregne, H.E. Land degradation in the drylands. Arid Land Res. Manag. 2002, 16, 99-132. [CrossRef]

17. FAO. Land Degradation in South Asia: Its Severity, Causes and Effects upon People, World Soil Resources Report, 78; FAO: Rome, Italy, 1994.

18. United Nations. Desertification: Its Causes and Consequences; Pergamon Press: Oxford, UK, 1977.

19. Mainguet, M. Desertification: Natural background and Human Mismanagement; Springer Science \& Business Media: Berlin, Germany, 2012.

20. Le Houerou, H.N. Land degradation in Mediterranean Europe: Can agroforestry be a part of the solution? A prospective review. Agrofor. Syst. 1993, 21, 43-61. [CrossRef]

21. Conacher, A.J. Land Degradation; Kluwer Academic Publishers: Dordrecht, The Netherlands, 2000.

22. Glantz, M.H. Desertification: Environmental Degradation in and around Arid Lands; CRC Press: Boca Raton, FL, USA, 2019.

23. Verstraete, M.M.; Brink, A.B.; Scholes, R.J.; Beniston, M.; Stafford Smith, M. Climate change and desertification: Where do we stand, where should we go? Glob. Planet. Chang. 2008, 64, 105-110. [CrossRef]

24. Vogt, J.V.; Safriel, U.; Bastin, G.; Zougmore, R.; von Maltitz, G.; Sokona, Y.; Hill, J. Monitoring and Assessment of Land Degradation and Desertification: Towards new conceptual and integrated approaches. Land Degrad. Dev. 2011, 22, 150-165. [CrossRef]

25. Torres, L.; Abraham, E.M.; Rubio, C.; Barbero-Sierra, C.; Ruiz-Pérez, M. Desertification research in Argentina. Land Degrad. Dev. 2015, 26, 433-440. [CrossRef]

26. Stringer, L.C.; Fleskens, L.; Reed, M.S.; de Vente, J.; Zengin, M. Participatory evaluation of monitoring and modeling of sustainable land management technologies in areas prone to land degradation. Environ. Manag. 2014, 54, 1022-1042. [CrossRef]

27. Puigdefábregas, J. Ecological impacts of global change on drylands and their implications for desertification. Land Degrad. Dev. 1998, 9, 393-406. [CrossRef]

28. Johnson, D.L.; Lewis, L.A. Land Degradation-Creation and Destruction; Rowman Littlefield Lahnam: Lanham, Maryland, 2017; pp. 216.

29. Johnson, P.M.; Mayrand, K.; Paquin, M. Governing Global Desertification: Linking Environmental Degradation, Poverty and Participation; Ashgate: London, UK, 2006.

30. Huang, J.; Zhang, G.; Zhang, Y.; Guan, X.; Wei, Y.; Guo, R. Global desertification vulnerability to climate change and human activities. Land Degrad. Dev. 2020. [CrossRef] 
31. Ibáñez, J.; Martinez Valderrama, J.; Puigdefabregas, J. Assessing desertification risk using system stability condition analysis. Ecol. Model. 2008, 213, 180-190. [CrossRef]

32. Imeson, A. Desertification, Land Degradation and Sustainability; Wiley: London, UK, 2012.

33. Hill, J.; Stellmes, M.; Udelhoven, T.; Röder, A.; Sommer, S. Mediterranean desertification and land degradation: Mapping related land use change syndromes based on satellite observations. Glob. Planet. Chang. 2008, 64, 146-157. [CrossRef]

34. FAO. Terminology for Integrated Resources Planning and Management; UN Food and Agriculture Organization: Rome, Italy, 1998.

35. Henry, B.; Murphy, B.; Cowie, A. Sustainable land management for environmental benefits and food security. In A Synthesis Report for the GEF (Global Environmental Facility); GEF: Washington, DC, USA, 2018.

36. Prăvălie, R. Drylands extent and environmental issues. A global approach. Earth Sci. Rev. 2016, 161, $259-278$. [CrossRef]

37. Prăvălie, R.; Bandoc, G.; Patriche, C.; Sternberg, T. Recent changes in global drylands: Evidences from two major aridity databases. Catena 2019, 178, 209-231. [CrossRef]

38. UNCCD. United Nations Convention to Combat Desertification in Those Countries Experiencing Serious Drought and/or Desertification, Particularly in Africa; UNCCD: Paris, France, 1994.

39. Helldén, U. A coupled Human-Environment model for desertification simulation and impact studies. Glob. Planet. Chang. 2008, 64, 158-168. [CrossRef]

40. Salvati, L.; Zitti, M.; Ceccarelli, T. Integrating economic and environmental indicators in the assessment of desertification risk: A case study. Appl. Ecol. Environ. Res. 2008, 6, 129-138. [CrossRef]

41. Salvati, L.; Zitti, M. Land degradation in the Mediterranean basin: Linking bio-physical and economic factors into an ecological perspective. Biota 2005, 5, 67-77.

42. Helldén, U.; Tottrup, C. Regional desertification: A global synthesis. Glob. Planet. Chang. 2008, 64, 169-176. [CrossRef]

43. Briassoulis, H. Governing desertification in Mediterranean Europe: The challenge of environmental policy integration in multi-level governance contexts. Land Degrad. Dev. 2011, 22, 313-325. [CrossRef]

44. Abu Hammad, A.; Tumeizi, A. Land degradation: Socioeconomic and environmental causes and consequences in the eastern Mediterranean. Land Degrad. Dev. 2012, 23, 216-226. [CrossRef]

45. Hooke, J.; Sandercock, P. Combating Desertification and Land Degradation: Spatial Strategies Using Vegetation; Springer: Berlin, Germany, 2017.

46. Briassoulis, H. Policy Integration for Complex Environmental Problems: The Example of Mediterranean Desertification; Routledge: London, UK, 2017.

47. Sfeir-Younis, A. Land and Soil Management: Technology, Economics, and Institutions; CRC Press: New York, NY, USA, 2019.

48. Blaikie, P. The Political Economy of Soil Erosion in Developing Countries; Routledge: London, UK, 2016.

49. Harte, J. Human population as a dynamic factor in environmental degradation. Popul. Environ. 2007, 28, 223-236. [CrossRef]

50. Hein, L. Assessing the costs of land degradation: A case study for the Puentes catchment, Southeast Spain. Land Degrad. Dev. 2007, 18, 631-642. [CrossRef]

51. Hein, L.; De Ridder, N. Desertification in theSahel: A reinterpretation. Glob. Chang. Biol. 2006, 12, 751-758. [CrossRef]

52. Behnke, R.; Mortimore, M. The End of Desertification? Springer: Berlin/Heidelberg, Germany, 2016.

53. Briassoulis, H. Combating land degradation and desertification: The land-use planning quandary. Land 2019, 8, 27. [CrossRef]

54. Cao, S.; Liu, Y.; Yu, Z. China's successes at combating desertification provide roadmap for other nations. Environ. Sci. Policy Sustain. Dev. 2018, 60, 16-24. [CrossRef]

55. Colantoni, A.; Ferrara, C.; Perini, L.; Salvati, L. Assessing trends in climate aridity and vulnerability to soil degradation in Italy. Ecol. Indic. 2015, 48, 599-604. [CrossRef]

56. Salvati, L.; Perini, L.; Sabbi, A.; Bajocco, S. Climate Aridity and Land Use Changes: A Regional-Scale Analysis. Geogr. Res. 2012, 50, 193-203. [CrossRef]

57. Salinas, C.X.; Mendieta, J. Mitigation and adaptation investments for desertification and climate change: An assessment of the socioeconomic return. Mitig. Adapt. Strateg. Glob. Chang. 2013, 18, 659-672. [CrossRef] 
58. Recanatesi, F.; Clemente, M.; Grigoriadis, E.; Ranalli, F.; Zitti, M.; Salvati, L. A fifty-year sustainability assessment of Italian agro-forest districts. Sustainability 2016, 8, 32. [CrossRef]

59. Nigussie, Z.; Tsunekawa, A.; Haregeweyn, N.; Adgo, E.; Nohmi, M.; Tsubo, M.; Abele, S. Factors influencing small-scale farmers' adoption of sustainable land management technologies in north-western Ethiopia. Land Use Policy 2017, 67, 57-64. [CrossRef]

60. Lambin, E. Spatial scales and desertification. Desertif. Control Bull. 1993, 23, 20-23.

61. Reynolds, J.; Smith, D.M.S.; Lambin, E.F.; Turner, B.L.; Mortimore, M.; Batterbury, S.P.J.; Downing, T.E.; Dowlatabadi, H.; Fernandez, R.J.; Herrick, J.E.; et al. Global desertification: Building a science for dryland development. Science 2007, 316, 847-851. [CrossRef] [PubMed]

62. Moreda, T. Contesting conventional wisdom on the links between land tenure security and land degradation: Evidence from Ethiopia. Land Use Policy 2018, 77, 75-83. [CrossRef]

63. Monarca, D.; Cecchini, M.; Guerrieri, M.; Colantoni, A. Conventional and alternative use of biomasses derived by hazelnut cultivation and processing. Acta Hortic. 2009, 845, 627-634. [CrossRef]

64. Leighton, M. Desertification and migration. In Governing Global Desertification; Routledge: London, UK, 2016; pp. 63-78.

65. Santini, M.; Caccamo, G.; Laurenti, A.; Noce, S.; Valentini, R. A multi-component GIS framework for desertification risk assessment by an integrated index. Appl. Geogr. 2010, 30, 394-415. [CrossRef]

66. Scherr, S.J. A downward spiral? Research evidence on the relationship between poverty and natural resource degradation. Food Policy 2000, 25, 479-498. [CrossRef]

67. Seely, M.; Wohl, H. Connecting research to combating desertification. Environ. Monit. Assess. 2004, 99, $23-32$. [CrossRef]

68. Scholes, R.J. Syndromes of dryland degradation in southern Africa. Afr. J. Range Forage Sci. 2009, 26, 113-125. [CrossRef]

69. Darkoh, M.B.K. The nature, causes and consequences of desertification in the drylands of Africa. Land Degrad. Dev. 1998, 9, 1-20. [CrossRef]

70. Dave, V.; Pandya, M.; Ghosh, R. Identification of Desertification Hot Spot Using Aridity Index. Ann. Arid Zone 2019, 58, 39-44.

71. Bajocco, S.; Salvati, L.; Ricotta, C. Land degradation versus fire: A spiral process? Prog. Phys. Geogr. 2011, 35, 3-18. [CrossRef]

72. Kessler, C.A.; Stroosnijder, L. Land degradation assessment by farmers in Bolivian mountain valleys. Land Degrad. Dev. 2006, 17, 235-248. [CrossRef]

73. Kishk, M.A. Combating desertification, is it always possible? The case of small Egyptian farmers. GeoJournal 1993, 31, 77-84. [CrossRef]

74. Mortimore, M.; Turner, B. Does the Sahelian smallholder's management of woodland, farm trees, rangeland support the hypothesis of human-induced desertification? J. Arid Environ. 2005, 63, 567-595. [CrossRef]

75. Mendelsohn, R.; Dinar, A. Climate, water, and agriculture. Land Econ. 2003, 79, 328-341. [CrossRef]

76. Martínez-Valderrama, J.; Ibáñez, J.; Del Barrio, G.; Sanjuán, M.E.; Alcalá, F.J.; Martínez-Vicente, S.; Puigdefábregas, J. Present and future of desertification in Spain: Implementation of a surveillance system to prevent land degradation. Sci. Total Environ. 2016, 563, 169-178. [CrossRef] [PubMed]

77. Sommer, S.; Zucca, C.; Grainger, A.; Cherlet, M.; Zougmore, R.; Sokona, Y.; Hill, J. Application of indicator systems for monitoring and assessment of desertification from national to global scales. Land Degrad. Dev. 2011, 22, 184-197. [CrossRef]

78. Stocking, M.; Murnaghan, N. Handbook for the Field Assessment of Land Degradation; Earthscan: London, UK, 2001.

79. Bridges, E.M. Response to Land Degradation; CRC Press: New York, NY, USA, 2019.

80. Fleskens, L.; Stringer, L.C. Land management and policy responses to mitigate desertification and land degradation. Land Degrad. Dev. 2014, 25, 1-4. [CrossRef]

81. Karamesouti, M.; Panagos, P.; Kosmas, C. Model-based spatio-temporal analysis of land desertification risk in Greece. Catena 2018, 167, 266-275. [CrossRef]

82. Giger, M.; Liniger, H.; Sauter, C.; Schwilch, G. Economic benefits and costs of sustainable land management technologies: An analysis of WOCAT's global data. Land Degrad. Dev. 2018, 29, 962-974. [CrossRef]

83. Gibbs, H.K.; Salmon, J.M. Mapping the world's degraded lands. Appl. Geogr. 2015, 57, 12-21. [CrossRef]

84. Geist, H.J.; Lambin, E.F. Dynamic causal patterns of desertification. Bioscience 2004, 54, 817-829. [CrossRef] 
85. Geist, H. The Causes and Progression of Desertification; Routledge: London, UK, 2017.

86. Fisher, B.; Turner, R.K.; Morling, P. Defining and classifying ecosystem services for decision making. Ecol. Econ. 2009, 68, 643-653. [CrossRef]

87. Ferrara, A.; Salvati, L.; Sateriano, A.; Nolè, A. Performance evaluation and cost assessment of a key indicator system to monitor desertification vulnerability. Ecol. Indic. 2012, 23, 123-129. [CrossRef]

88. Zelnik, Y.R.; Uecker, H.; Feudel, U.; Meron, E. Desertification by front propagation? J. Theor. Biol. 2017, 418, 27-35. [CrossRef]

89. Zambon, I.; Benedetti, A.; Ferrara, C.; Salvati, L. Soil matters? A multivariate analysis of socioeconomic constraints to urban expansion in Mediterranean Europe. Ecol. Econ. 2018, 146, 173-183. [CrossRef]

90. Yan, X.; Cai, Y.L. Multi-scale anthropogenic driving forces of karst rocky desertification in Southwest China. Land Degrad. Dev. 2015, 26, 193-200. [CrossRef]

91. Walpole, S.; Sinden, J.; Yapp, T. Land quality as an input of production: The case of land degradation and agricultural output. Econ. Anal. Policy 1996, 26, 185-207. [CrossRef]

92. $\mathrm{Xu}, \mathrm{D}$.; Ding, $\mathrm{X}$. Assessing the impact of desertification dynamics on regional ecosystem service value in North China from 1981 to 2010. Ecosyst. Serv. 2018, 30, 172-180. [CrossRef]

93. Wiebe, K. Land Quality and Land Degradation-Implications for Agricultural Productivity and Food Security at Farm, Regional and Global Scales; Edward Elgar: Chichester, UK, 2003.

94. Wang, X.; Chen, F.; Dong, Z. The relative role of climatic and human factors in desertification in semiarid China. Glob. Environ. Chang. 2006, 16, 48-57. [CrossRef]

95. Varghese, N.; Singh, N.P. Linkages between land use changes, desertification and human development in the Thar Desert Region of India. Land Use Policy 2016, 51, 18-25. [CrossRef]

96. Salvati, L.; Zitti, M. Regional convergence of environmental variables: Empirical evidences from land degradation. Ecol. Econ. 2008, 68, 162-168. [CrossRef]

97. De Pina Tavares, J.; Baptista, I.; Ferreira, A.J.D.; Amiotte-Suchet, P.; Coelho, C.; Gomes, S.; Amoros, R.; Amarildo Dos Reis, E.; Mendes, A.F.; Costa, L.; et al. Assessment and mapping the sensitive areas to desertification in an insular Sahelian mountain region. Case study of the Ribeira Seca Watershed, Santiago Island, Cabo Verde. Catena 2015, 128, 214-223. [CrossRef]

98. Karamesouti, M.; Detsis, V.; Kounalaki, A.; Vasiliou, P.; Salvati, L.; Kosmas, C. Land-use and land degradation processes affecting soil resources: Evidence from a traditional Mediterranean cropland (Greece). Catena 2015, 132, 45-55. [CrossRef]

99. Lavado Contador, J.F.; Schnabel, S.; Gómez Gutiérrez, A.; Pulido Fernandez, M. Mapping sensitivity to land degradation in Extremadura, SW Spain. Land Degrad. Dev. 2009, 20, 129-144. [CrossRef]

100. Leman, N.; Ramli, M.F.; Khirotdin, R.P.K. GIS-based integrated evaluation of environmentally sensitive areas (ESAs) for land use planning in Langkawi, Malaysia. Ecol. Indic. 2016, 61, 293-308. [CrossRef]

101. Salvati, L.; Gemmiti, R.; Perini, L. Land degradation in Mediterranean urban areas: An unexplored link with planning? Area 2012, 44, 317-325. [CrossRef]

102. Colantoni, A.; Mavrakis, A.; Sorgi, T.; Salvati, L. Towards a 'polycentric'landscape? Reconnecting fragments into an integrated network of coastal forests in Rome. Rend. Lincei 2015, 26, 615-624. [CrossRef]

103. Prăvălie, R.; Patriche, C.; Bandoc, G. Quantification of land degradation sensitivity areas in Southern and Central Southeastern Europe. New results based on improving DISMED methodology with new climate data. Catena 2017, 158, 309-320. [CrossRef]

104. Prăvălie, R.; Săvulescu, I.; Patriche, C.; Dumitraşcu, M.; Bandoc, G. Spatial assessment of land degradation sensitive areas in southwestern Romania using modified MEDALUS method. Catena 2017, 153, 114-130. [CrossRef]

105. Prăvălie, R.; Patriche, C.; Săvulescu, I.; Sîrodoev, I.; Bandoc, G.; Sfîcă, L. Spatial assessment of land sensitivity to degradation across Romania. A quantitative approach based on the modified MEDALUS methodology. Catena 2020. [CrossRef]

106. Salvati, L.; Zitti, M.; Perini, L. Fifty years on: Long-term patterns of land sensitivity to desertification in Italy. Land Degrad. Dev. 2016, 27, 97-107. [CrossRef]

107. Symeonakis, E.; Karathanasis, N.; Koukoulas, S.; Panagopoulos, G. Monitoring sensitivity to land degradation and desertification with the Environmentally Sensitive Area Index: The case of Lesvos island. Land Degrad. Dev. 2016, 27, 1562-1573. [CrossRef] 
108. Xu, D.; You, X.; Xia, C. Assessing the spatial-temporal pattern and evolution of areas sensitive to land desertification in North China. Ecol. Indic. 2019, 97, 150-158. [CrossRef]

109. Requier-Desjardins, M. Economic costs of desertification: A first survey of some cases in Africa. Int. J. Sustain. Dev. 2006, 9, 199-209. [CrossRef]

110. Pessarakli, M.; Moradi, E.; Mirdeilami, S.Z. The Role of Local Settlements in Combating Desertification of Isfahan's Desert Rangelands. J. Rangel. Sci. 2019, 9, 202-218.

111. Nkonya, E.; Mirzabaev, A.; Von Braun, J. Economics of Land Degradation and Improvement: A Global Assessment for Sustainable Development; Springer: Cham, Switzerland, 2016; Volume 686.

112. Wilson, G.; Quaranta, G.; Kelly, C.; Salvia, R. Community resilience, land degradation and endogenous lock-in effects: Evidence from the Alento region, Campania, Italy. J. Environ. Plan. Manag. 2016, 59, 518-537. [CrossRef]

113. Vu, Q.M.; Le, Q.B.; Frossard, E.; Vlek, P.L. Socio-economic and biophysical determinants of land degradation in Vietnam: An integrated causal analysis at the national level. Land Use Policy 2014, 36, 605-617. [CrossRef]

114. Smiraglia, D.; Ceccarelli, T.; Bajocco, S.; Salvati, L.; Perini, L. Linking trajectories of land change, land degradation processes and ecosystem services. Environ. Res. 2016, 147, 590-600. [CrossRef]

115. Thomas, D.S. Science and the desertification debate. J. Arid Environ. 1997, 37, 599-608. [CrossRef]

116. Xu, D.; Li, C.; Zhuang, D.; Pan, J. Assessment of the relative role of climate change and human activities in desertification: A review. J. Geogr. Sci. 2011, 21, 926-936. [CrossRef]

117. Xie, H.; Zhang, Y.; Wu, Z.; Lv, T. A Bibliometric Analysis on Land Degradation: Current Status, Development, and Future Directions. Land 2020, 9, 28. [CrossRef]

118. Geeson, N.A.; Brandt, C.J.; Thornes, J.B. Mediterranean Desertification: A Mosaic of Processes and Responses; Wiley: London, UK, 2003.

119. Delfanti, L.; Colantoni, A.; Recanatesi, F.; Bencardino, M.; Sateriano, A.; Zambon, I.; Salvati, L. Solar plants, environmental degradation and local socioeconomic contexts: A case study in a Mediterranean country. Environ. Impact Assess. Rev. 2016, 61, 88-93. [CrossRef]

120. Ceccarelli, T.; Bajocco, S.; Perini, L.; Salvati, L. Urbanisation and land take of high quality agricultural soils-exploring long-term land use changes and land capability in Northern Italy. Int. J. Environ. Res. 2014, 8, 181-192.

121. Barbero-Sierra, C.; Marques, M.J.; Ruíz-Pérez, M. The case of urban sprawl in Spain as an active and irreversible driving force for desertification. J. Arid Environ. 2013, 90, 95-102. [CrossRef]

122. Cheng, L.; Lu, Q.; Wu, Q.; Yin, C.; Bao, Y.; Gong, L. Estimation of the costs of desertification in China: A critical review. Land Degrad. Dev. 2018, 29, 975-983. [CrossRef]

123. Bojo, J. Economics and land degradation. Ambio 1991, 2002, 75-79.

124. Cuffaro, N. Population, Economic Growth and Agriculture in Less Developed Countries; Psychology Press: New York, NY, USA, 2001; Volume 23.

125. Esposito, P.; Patriarca, F.; Salvati, L. Tertiarization and land use change: The case of Italy. Econ. Model. 2018, 71, 80-86. [CrossRef]

126. Assefa, E.; Hans-Rudolf, B. Farmers' perception of land degradation and traditional knowledge in Southern Ethiopia-Resilience and stability. Land Degrad. Dev. 2016, 27, 1552-1561. [CrossRef]

127. Cacho, O. An analysis of externalities in agroforestry systems in the presence of land degradation. Ecol. Econ. 2001, 39, 131-143. [CrossRef]

128. Beaumont, P.M.; Walker, R.T. Land degradation and property regimes. Ecol. Econ. 1996, 18, 55-66. [CrossRef]

129. Ferrara, A.; Kosmas, C.; Salvati, L.; Padula, A.; Mancino, G.; Nolè, A. Updating the MEDALUS-ESA Framework for Worldwide Land Degradation and Desertification Assessment. Land Degrad. Dev. 2020. [CrossRef]

130. Gonzalez-Roglich, M.; Zvoleff, A.; Noon, M.; Liniger, H.; Fleiner, R.; Harari, N.; Garcia, C. Synergizing global tools to monitor progress towards land degradation neutrality: Trends. Earth and the World Overview of Conservation Approaches and Technologies sustainable land management database. Environ. Sci. Policy 2019, 93, 34-42. [CrossRef]

131. Fernandez, R.J. Do humans create deserts? Trends Ecol. Evol. 2002, 17, 6-7. [CrossRef]

132. Graves, A.R.; Morris, J.; Deeks, L.K.; Rickson, R.J.; Kibblewhite, M.G.; Harris, J.A.; Truckle, I. The total costs of soil degradation in England and Wales. Ecol. Econ. 2015, 119, 399-413. [CrossRef]

133. Hone, P. Assessing the Private Costs of Soil Degradation. Econ. Anal. Policy 1992, 22, 149-160. [CrossRef] 
134. Kirby, M.G.; Blyth, M.J. Economic aspects of land degradation in Australia. Aust. J. Agric. Econ. 1987, 31, 154-174. [CrossRef]

135. National Research Council. Understanding the Changing Planet: Strategic Directions for the Geographical Sciences; National Academies Press: Washington, DC, USA, 2010.

136. Hubacek, K.; van den Bergh, J.C.J.M. Changing concepts of land' in economic theory: From single to multi-disciplinary approaches. Ecol. Econ. 2006, 56, 5-27. [CrossRef]

137. Shiferaw, B.; Holden, S.T. Farm-level benefits to investments for mitigating land degradation: Empirical evidence from Ethiopia. Environ. Dev. Econ. 2001, 6, 335-358. [CrossRef]

138. Requier-Desjardins, M.; Adhikari, B.; Sperlich, S. Some notes on the economic assessment of land degradation. Land Degrad. Dev. 2011, 22, 285-298. [CrossRef]

139. Pender, J.L. Population growth, agricultural intensification, induced innovation and natural resource sustainability: An application of neoclassical growth theory. Agric. Econ. 1998, 19, 99-112. [CrossRef]

140. Wei, X.; Zhou, L.; Yang, G.; Wang, Y.; Chen, Y. Assessing the Effects of Desertification Control Projects from the Farmers' Perspective: A Case Study of Yanchi County, Northern China. Int. J. Environ. Res. Public Health 2020, 17, 983. [CrossRef] [PubMed]

141. Zuindeau, B. Territorial equity and sustainable development. Environ. Values 2007, 16, 253-268. [CrossRef]

142. Zitti, M.; Ferrara, C.; Perini, L.; Carlucci, M.; Salvati, L. Long-term urban growth and land use efficiency in Southern Europe: Implications for sustainable land management. Sustainability 2015, 7, 3359-3385. [CrossRef]

143. Juntti, M.; Wilson, G.A. Conceptualising desertification in southern Europe: Stakeholders interpretations and multiple policy agendas. Eur. Environ. 2004, 15, 228-249. [CrossRef]

144. Barbier, E.B.; Hochard, J.P. Does land degradation increase poverty in developing countries? PLoS ONE 2016, 11, e0152973. [CrossRef]

145. Chopra, K.; Gulati, S.C. Environmental degradation and population movements: The role of property rights. Environ. Resour. Econ. 1997, 9, 383-408. [CrossRef]

146. Bao, H.; Li, Z.; Wang, T. Conceptual model of sustainable development in sand-desertification region, China. Sci. Geogr. Sin. 2007, 27, 173.

147. Yang, L.; Wu, J. Seven design principles for promoting scholars' participation in combating desertification. Int. J. Sustain. Dev. World Ecol. 2010, 17, 109-119. [CrossRef]

148. Singh, J.; Singh, J.P. Land degradation and economic sustainability. Ecol. Econ. 1995, 15, 77-86. [CrossRef]

149. Singh, R.B. A composite method to identify desertification 'hotspots' and 'brightspots'. Land Degrad. Dev. 2019, 30, 1025-1039. [CrossRef]

150. Barbier, E.B.; Hochard, J.P. Land degradation and poverty. Nat. Sustain. 2018, 1, 623-631. [CrossRef]

151. de Groot, R.S.; Alkemade, R.; Braat, L.; Hein, L.; Willemen, L. Challenges in integrating the concept of ecosystem services and values in landscape planning, management and decision making. Ecol. Complex. 2010, 7, 260-272. [CrossRef]

152. Arrow, K.; Bolin, B.; Costanza, R.; Dasgupta, P.; Folke, C.; Holling, C.S.; Jansson, B.-O.; Levin, S.; Mäler, K.-G.; Perrings, C.; et al. Economic Growth, Carrying Capacity, and the Environment. Science 1995, 268, 520-521. [CrossRef]

153. Costanza, R.; d'Arge, R.; de Groot, R.; Farber, S.; Grasso, M.; Hannon, B.; Limburg, K.; Naeem, S.; Oneill, R.V.; Paruelo, J.; et al. The value of the world's ecosystem services and natural capital. Nature 1997, 387, 253-260. [CrossRef]

154. Pieratti, E.; Paletto, A.; Atena, A.; Bernardi, S.; Palm, M.; Patzel, D.; Romagnoli, M.; Teston, F.; Voglar, G.; Grebenec, T.; et al. Environmental and climate change impacts of eighteen biomass-based plants in the alpine region: A comparative analysis. J. Clean. Prod. 2019, 242, 118449.

155. Paletto, A.; Bernardi, S.; Pieratti, E.; Teston, F.; Romagnoli, M. Assessment of environmental impact of biomass power plants to increase the social acceptance of renewable energy technologies. Helyon 2019, 5, e02070. [CrossRef]

156. Moresi, F.; Maesano, M.; Matteucci, G.; Romagnoli, M.; Sidle, R.; Scarascia Mugnozza, G. Root Biomechanical Traits in a Montane Mediterranean Forest Watershed: Variations with species Diversity and Soil Depth. Forests 2019, 10, 341. [CrossRef] 
157. Romagnoli, M.; Moroni, S.; Recanatesi, F.; Salvati, R.; Scarascia Mugnozza, G. Climate factors and oak decline based on tree-ring analysis. A case study in peri-urban forest in the Mediterranean area. Urban For. Urban Green. 2018, 34, 17-28. [CrossRef]

158. Pender, J.; Nkonya, E.; Jagger, P.; Sserunkuuma, D.; Ssali, H. Strategies to increase agricultural productivity and reduce land degradation: Evidence from Uganda. Agric. Econ. 2004, 31, 181-195. [CrossRef]

159. Blaikie, P.; Brookfield, H.C. Land Degradation and Society; Methuen: London, UK, 1987.

160. Bojo, J. The costs of land degradation in sub-Saharan Africa. Ecol. Econ. 1996, 18, 55-66. [CrossRef]

161. Stavi, I.; Lal, R. Achieving zero net land degradation: Challenges and opportunities. J. Arid Environ. 2015, 112, 44-51. [CrossRef]

162. Chasek, P.; Safriel, U.; Shikongo, S.; Fuhrman, V.F. Operationalizing zero net land degradation: The next stage in international efforts to combat desertification? J. Arid Environ. 2015, 112, 5-13. [CrossRef]

163. Tal, A. The implications of environmental trading mechanisms on a future Zero Net Land Degradation protocol. J. Arid Environ. 2015, 112, 25-32. [CrossRef]

164. Salvati, L.; Carlucci, M. Zero Net Land Degradation in Italy: The role of socioeconomic and agro-forest factors. J. Environ. Manag. 2014, 145, 299-306. [CrossRef]

165. Squires, V.R.; Ariapour, A. Desertification: Past, Current and Future Trends; Nova Science Publishers Inc.: New York, NY, USA, 2018.

(C) 2020 by the authors. Licensee MDPI, Basel, Switzerland. This article is an open access article distributed under the terms and conditions of the Creative Commons Attribution (CC BY) license (http://creativecommons.org/licenses/by/4.0/). 